\title{
Silver recovery from zinc metallurgical sludge - analysis of solutions
}

\author{
Stanisław Pietrzyk ${ }^{1}$, Piotr Palimąka ${ }^{1}$, Michat Stępień ${ }^{1}$, Aldona Krawczykowska $^{2}$, Barbara Tora $^{2,}{ }^{*}$, Mirosław Fatyga ${ }^{3}$, \\ Grażyna Pajor $^{3}$, and Arkadiusz Mańka ${ }^{3}$ \\ ${ }^{1}$ AGH University of Science and Technology, Faculty of Non-Ferrous Metals, Kraków, Poland \\ ${ }^{2}$ AGH University of Science and Technology, Faculty of Mining and Geoengineering, Kraków, Poland \\ ${ }^{3}$ Górniczo-Hutnicze „Bolesław” S.A, Kolejowa 37, 32-332 Bukowno, Poland
}

\begin{abstract}
During the hydrometallurgical process of zinc production, conducted in the ZGH "Bolesław" S.A. in Bukowno [Mine and Metallurgical Plant], about 40,000 tons of sludge is generated. After dehydration in the Larox filter presses, sludge contains ca. $16-18 \%$ of $\mathrm{Zn}, 20-25 \%$ of Fe, and $200-300 \mathrm{ppm}$ of Ag. Next, sludge is transported to the Olkusz concentrator for flotation to obtain concentrate enriched with $\mathrm{Ag}(1,000-1,500 \mathrm{ppm})$. The concentrate is then sent to the HC "Miasteczko Śląskie" [zinc smelter], while the flotation tailings are subjected to recycling in waelz kiln in Bukowno to regain mainly $\mathrm{Zn}$ and $\mathrm{Pb}$, in the form of oxides (also sent later to the HC "Miasteczko Śląskie").
\end{abstract}

\section{Introduction}

During the hydrometallurgical process of zinc production, conducted in the ZGH "Bolesław" S.A. in Bukowno [mine and metallurgical plant], about 40,000 tons of sludge is generated. After dehydration in the Larox filter presses, sludge contains ca. $16-18 \%$ of $\mathrm{Zn}, 20-25 \%$ of Fe, and 200-300ppm of Ag. Next, sludge is transported to the Olkusz concentrator for flotation to obtainconcentrate enriched with Ag (1,000-1,500 ppm). The concentrate is then sent to the HC "Miasteczko Śląskie" [zinc smelter], while the flotation tailings are subjected to recycling in waelz kiln in Bukowno to regain mainly $\mathrm{Zn}$ and $\mathrm{Pb}$, in the form of oxides (also sent later to the $\mathrm{HC}$ "Miasteczko Śląskie") [1].

It seems to be reasonable to consider a possibility of sludge flotation after acid leaching, directly at the ZGH "Bolesław" plant. That will allow to reduce costs by elimination of transportation to the enrichment plant, as well as develop a flotation technology dedicated to those types of materials. Preparation of a new flotation technology is intended to increase silver output, in comparison to the presently used method, with a concurrent examination of managing the remaining solutions, in the conditions of the existing process lines.

\section{Zinc production technology in the hydrometallurgical process}

The hydrometallurgical zinc production process conducted in the ZGH "Bolesław" S.A. plant in Bukowno involves the following operations:

- roasting of the zinc concentrate in a fluidised condition,
- roasted concentrate leaching,

- separation of sludge and insoluble fractions of the roasted concentrate from the zinc sulphate solution (sedimentation and filtration),

- removal of impurities from the zinc sulphate solution by hydrolysis and cementation,

- electrolysis of the water solution of zinc sulphate.

Table 1. Chemical analysis of flotation zinc calcine [1]

\begin{tabular}{|c|c|c|c|c|c|c|c|}
\hline Element & $\mathbf{Z n}$ & $\mathbf{P b}$ & $\mathbf{F e}$ & $\mathbf{C d}$ & $\mathbf{A s}$ & $\mathbf{F}$ & $\mathbf{C l}$ \\
\hline $\begin{array}{c}\text { Content } \\
{[\%]}\end{array}$ & 63.68 & 1.86 & 5.03 & 0.31 & 0.066 & 0.003 & 0.009 \\
\hline
\end{tabular}

The basic input material for the "Bolesław" smelter consists in sulphide concentrates of zinc delivered from the "Olkusz" mine and concentrator and partly imported. Zinc concentrate is obtained by flotation. It contains ca. $50-55 \%$ of $\mathrm{Zn}, 25-30 \%$ of $\mathrm{S}$, less than $2 \%$ of $\mathrm{Pb}$, less than $8 \%$ of Fe, and small quantities of silver, as well as other compounds. After the flotation process, the concentrate needs to be dehydrated The concentrate $\mathrm{s}$ mixed, in specific proportions, with water to produce the so-called pulp. The material also contains up to $20 \%$ of added secondary zinc-containing material (Waelz zinc oxide), after previous dechlorination. The feed prepared in that way is directed into the fluidised-bed furnace. Air is supplied to the furnace by blowers and the process is conducted in the temperature of ca. $950^{\circ} \mathrm{C}$. roasting of fluidised concentrate is a process which does not require any fuel supply (the sulphide oxidation reactions are strongly exothermal). The roasted concentrate produced as a result of sulphide concentrate oxidation leaves the furnace through two channels. Coarse fractions, in the

\footnotetext{
Corresponding author: tora@agh.edu.pl
} 
proportion of ca. $60 \%$, are poured directly from the fluidisation zone to the cooling chamber and the calcine container. Small fractions, in the proportion of ca. $40 \%$, in the form of dust, are removed from the fluidisation zone to the upper section of the furnace, and they leave the furnace, together with $\mathrm{SO}_{2}$ containing off-gases. Next, gases flow through a set of cyclones for further dedusting. Clean gases are directed to the sulphuric acid plant. The composition of calcine is specified in Table 1.

The general diagram of the hydrometallurgical zinc concentrate processing in the ZGH "Bolesław" is presented in Fig. 1.

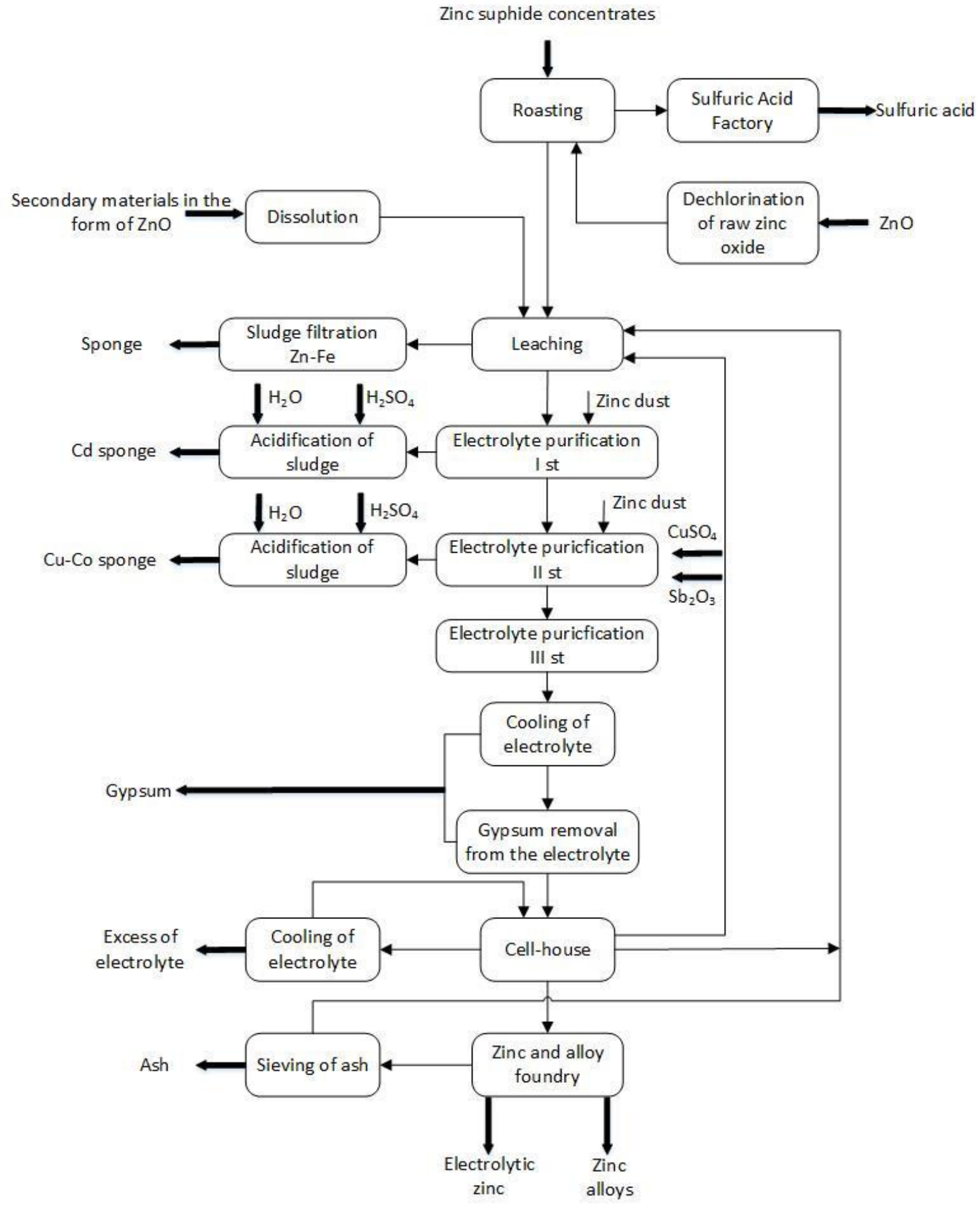

Fig. 1. Diagram of roasted zinc concentrate processing in the ZGH "Bolesław" in Bukowno (after [2]). 
The roasted material originating from the fluidisedbed furnace and the dusts collected by the dedusting systems are sent to the leaching process line. The purpose of this operation is to transfer the maximum quantity of the metal from solid phase to liquid phase. Sulphuric acid solution(VI) is the leaching agent. During leaching the hydrolytical precipitation of certain impurities (Fe, As, $\mathrm{Sb}, \mathrm{Ge}$ etc.) takes place. Presently, the ZGH "Bolesław" smelter applies a two-stage neutral leaching process that is conducted in the reactors with the capacity of $80 \mathrm{~m}^{3}$ each. The process is continuous and characterised by easy control. Calcine leaching is conducted by acidic return electrolyte, containing $40-50 \mathrm{~g} / \mathrm{dm}^{3}$ of $\mathrm{Zn}$ and up to $12 \%$ of $\mathrm{H}_{2} \mathrm{SO}_{4}$. During the leaching process, $\mathrm{pH}$ is changing from 3.0 in the first reactor to ca. 5.0 in the last one. During that process, ca. $85 \%$ of zinc is transferred to the solution. After leaching, pulp is directed to hydrocyclones in order to separate non-leached sand. Overflow is fed to the Dorr settler, and underflowis directed to the acid leaching line. Fig. 2 presents the diagram of roasted zinc concentrate processing in the Leaching Plant of the ZGH "Bolesław" in Bukowno.

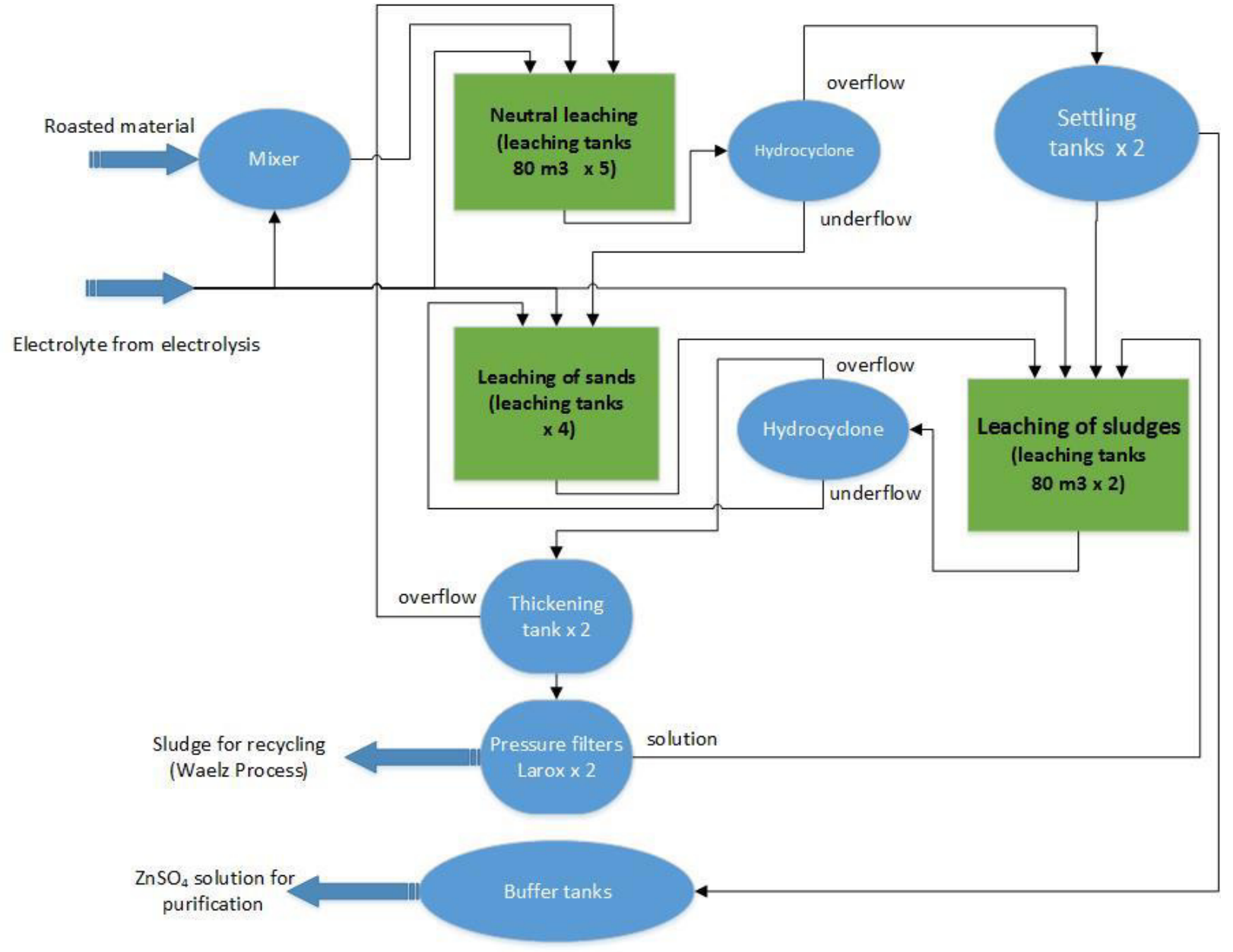

Fig. 2. Diagram of the roasted zinc concentrate processing in the Leaching Plant of the ZGH "Bolesław" in Bukowno (after [2]).

The solution collected from settling tanks is directed to the buffer tanks and later to the process of the -three- tages purification by cementation with zinc dust. After that purification process, electrolyte containing ca. $140 \mathrm{~g} / \mathrm{cm}^{3}$ of $\mathrm{Zn}$ is obtained. After cooling, it is fed to electrowinning cells. Sludge originating from the Dorr settlers is subjected again to leaching in the set of acid-neutral reactors and, after concentration and dehydration at Larox press filters, the zinc content is available at the level of $15-17 \%$. Sludge is then directed to two leaching reactors, $80 \mathrm{~m}^{3}$ each, followed by classification in a hydrocyclone. The overflow material from the hydrocyclone is subjected to concentration and the underflow returns to acid leaching of sands. Concentrated sludge is directed to the Larox press filters. The filtration residue, containing large quantities of zinc, iron, and lead, presented in Fig. 2, is fed to waelz kiln. Finally, zinc oxide is obtained.

The correct course of the electrolytic process requires high-purity electrolyte. The most important admixtures that have to be removed from electrolyte are the following: iron (II), cobalt, nickel, copper, and cadmium and the compounds of antimony and arsenic. Other impurities are removed periodically, as they concentrate in electrolyte and after they have exceeded the allowed concentrations.

The main impurities are removed during neutral leaching, as a result of the course of hydrolytic reaction (1-7)

$$
\mathrm{FeSO}_{4}+{ }_{2} \mathrm{H}_{2} \mathrm{O} \rightarrow \mathrm{Fe}(\mathrm{OH})_{2} \downarrow+\mathrm{H}_{2} \mathrm{SO}_{4}
$$

\footnotetext{
$\overline{\text { * Corresponding author: tora@agh.edu.pl }}$
} 


$$
\begin{gathered}
\mathrm{Fe}_{2}\left(\mathrm{SO}_{4}\right)_{3}+6 \mathrm{H}_{2} \mathrm{O} \rightarrow 2 \mathrm{Fe}(\mathrm{OH})_{3} \downarrow+3 \mathrm{H}_{2} \mathrm{SO}_{4} \\
\mathrm{Fe}_{2}\left(\mathrm{SO}_{4}\right)_{3}+3 \mathrm{ZnO}+3 \mathrm{H}_{2} \mathrm{O} \rightarrow \\
\rightarrow 2 \mathrm{Fe}(\mathrm{OH})_{3} \downarrow+3 \mathrm{ZnSO}_{4} \\
\mathrm{As}_{2}\left(\mathrm{SO}_{4}\right)_{3}+3 \mathrm{ZnO}+3 \mathrm{H}_{2} \mathrm{O} \rightarrow \\
\rightarrow \mathrm{As}_{2} \mathrm{O} 3 \cdot 3 \mathrm{H}_{2} \mathrm{O} \downarrow+3 \mathrm{ZnSO}_{4} \\
2 \mathrm{FeSO}_{4}+\mathrm{MnO}_{2}+\mathrm{H}_{2} \mathrm{SO}_{4} \rightarrow \\
\rightarrow \mathrm{Fe}_{2}\left(\mathrm{SO}_{4}\right)_{3}+\mathrm{MnSO}_{4}+2 \mathrm{H}_{2} \mathrm{O} \\
10 \mathrm{FeSO}_{4}+2 \mathrm{KMnO}_{4}+8 \mathrm{H}_{2} \mathrm{SO}_{4} \rightarrow \\
\rightarrow 5 \mathrm{Fe}_{2}\left(\mathrm{SO}_{4}\right)_{3}+2 \mathrm{MnSO}_{4}+\mathrm{K}_{2} \mathrm{SO}_{4}+8 \mathrm{H}_{2} \mathrm{O} \\
\mathrm{Sb}_{2}\left(\mathrm{SO}_{4}\right)_{3}+3 \mathrm{ZnO}+3 \mathrm{H}_{2} \mathrm{O} \rightarrow \\
\rightarrow \mathrm{Sb}_{2} \mathrm{O}_{3} * 3 \mathrm{H}_{2} \mathrm{O} \downarrow+3 \mathrm{ZnSO}_{4}
\end{gathered}
$$

The purification of zinc sulphide solution by cementation (in accordance with basic reactions 8 and 9) is conducted continually.

$$
\begin{aligned}
& \mathrm{Zn}+\mathrm{Cu}^{+2} \leftrightarrow \mathrm{Cu} \downarrow+\mathrm{Zn}^{+2} \\
& \mathrm{Zn}+\mathrm{Cd}^{+2} \leftrightarrow \mathrm{Cd} \downarrow+\mathrm{Zn}^{+2}
\end{aligned}
$$

Neutral overflow from the sedimentation tank contains ca. $135 \mathrm{~g} / \mathrm{l}$ of $\mathrm{Zn}, 470 \mathrm{mg} / \mathrm{l}$ of $\mathrm{Cu}, 170 \mathrm{mg} / \mathrm{l}$ of Cd etc. The material is fed to cementation tanks situated in a cascade. All the tanks are fed with zinc dust suspension. Sludge is pumped out from the last box to filter presses. After the first stage, filtrate is directed to the second stage of hot purification that is conducted in four cementators with the capacity of $120 \mathrm{~m}^{3}$ each. Zinc dust and reaction activators, $\mathrm{CuSO}_{4}$ and $\mathrm{Sb}_{2} \mathrm{O}_{3}$, are added. Before the second stage of purification, electrolyte is heated to $95^{\circ} \mathrm{C}$. The generated $\mathrm{Cu}-\mathrm{Co}$ sponge, containing a high proportion of zinc, is filtered at filter presses. The filtrate is sent to the zinc production line through a zinc electrolyte cooling and seasoning system, while sludge is directed to the acid treatment installation to recover zinc.

Leached and purified water solution of zinc sulphate is delivered to the cell-house where it is subjected to electrolysis. The working capacity of one cell amounts to $2.5 \mathrm{~m}^{3}$. Cells are arranged in an individual power supply system, 12 in two rows of 6 each, and grouped in two power units. Cascades are connected in series, with the electrodes connected in parallel. Anodes used in the zinc electrolysis process are made of lead, with $1 \%$ of silver. The number of anodes is 28 in each tank. Cathodes are made of high-purity ( $\min .99 .5 \%$ ) aluminium plates. The number of cathodes in each tank is one less than that of anodes (27). Zinc deposited as a result of direct current flow is removed from cathode starter sheets every 24 hours. The last stage consists in cathode melting in lowfrequency induction furnaces.. Liquid zinc flows through a system of half-pipes to cast-iron moulds where it solidifies and is extracted in the form of zinc ingot at the end of the casting line.

\section{Research purpose}

The technology of silver recovery from post-process sludge by the inclusion of the flotation process was implemented in 2012. Earlier, the sludge from zinc hydrometallurgy was delivered entirely to the Bolesław recycling plant and processed in waelz kiln (Fig. 3).

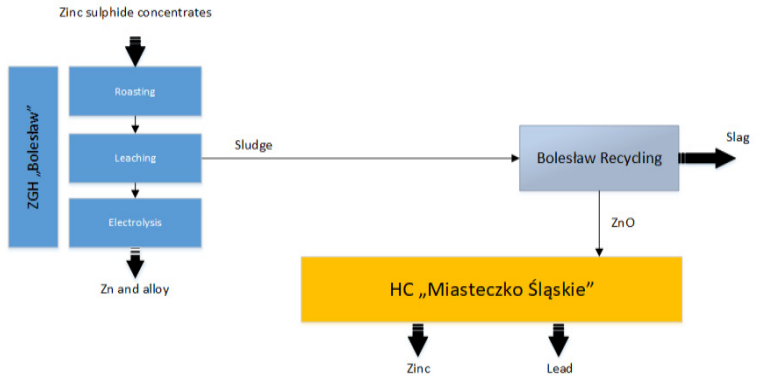

Fig. 3. Diagram of post-leaching sludge processing before 2012 .

Raw zinc oxide is the main product of the waelz process, together with slag. The analysis of the abovementioned products demonstrated that silver contained in the sludge is transferred mainly to slag (ca. 83\%) of the waelz process.

\section{Location of silver flotation in the technological process of zinc metallurgy - analysis of world solutions}

Analysis of the possible location of flotation in the technological process was based on the data contained in the book of Brook Hunt [1].

Brook Hunt \& Associates Ltd. provides research services for base and precious metal industries and markets. The company offers metals market services that track short and the long-term outlook for metal and concentrate markets; and cost services that analyze mine, smelter, and refinery production costs within base and precious metal industries. It also provides concentrates services, which analyze the flow of base metal concentrates from mines to smelters and refineries, as well as forecast concentrate market balances, and outlook for treatment and refining charges. In addition, the company offers metals consulting services. It provides its research on various metals, such as aluminum, copper gold, lead, nickel, and zinc. The company was founded in 1975 and is based in United Kingdom. On the figures 4,5 and 6 the world solution of zinc electrolytic plants are shown, fig. 5 shows the plants without silver flotation, fig. 6 with silver flotation [7]. 


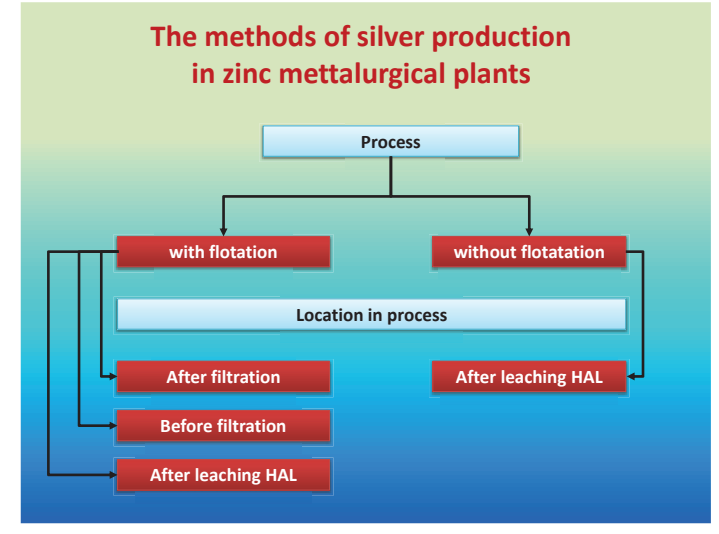

Fig. 4. Location of silver flotation in technological scheme of zinc production.

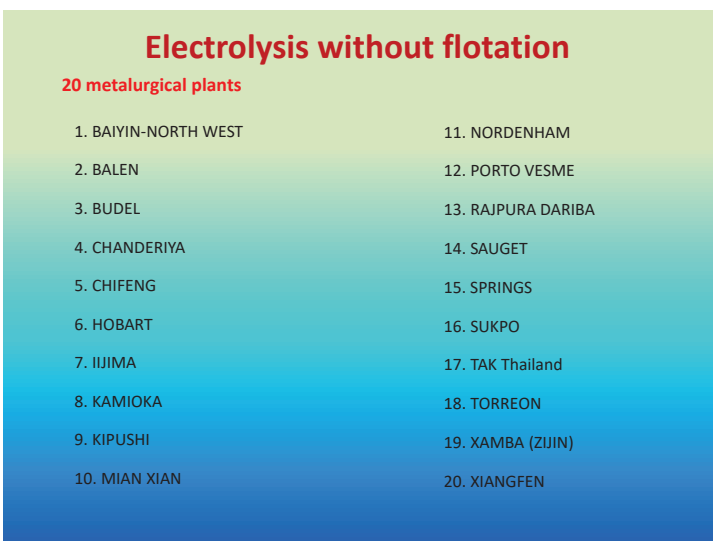

Fig. 5. List of world installations for zinc electrolysis - without silver flotation.

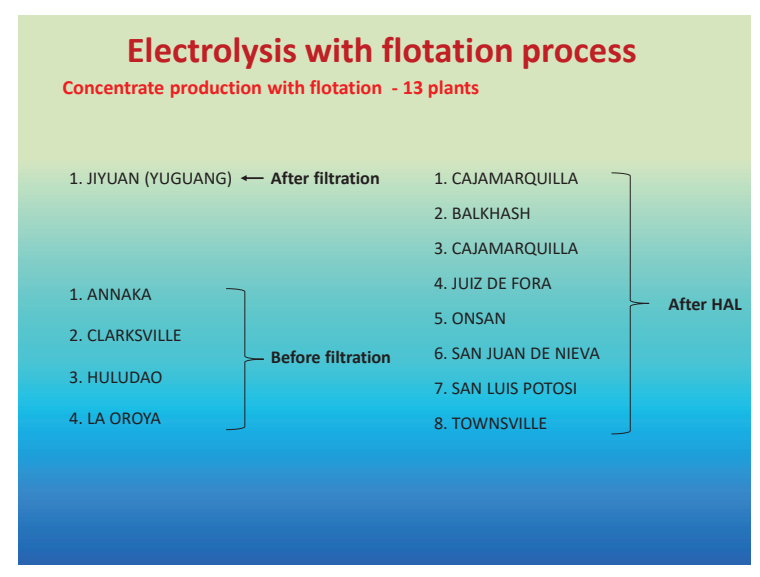

Fig. 6. Summary of world installations for zinc electrolysis with flotation.

\section{ZGH Bukowno case}

Presently, sludge is transported from the leaching plant to the ZPM Olkusz Pomorzany concentrator and subjected to the flotation process. The output concentrate, enriched with zinc and silver, is delivered to the HC "Miasteczko Śląskie", while tailings to the Bolesław Recycling Sp.
Z o.o., (from July 2017 is a part of ZGH Bolesław) as shown in Fig. 7.[5, 8].

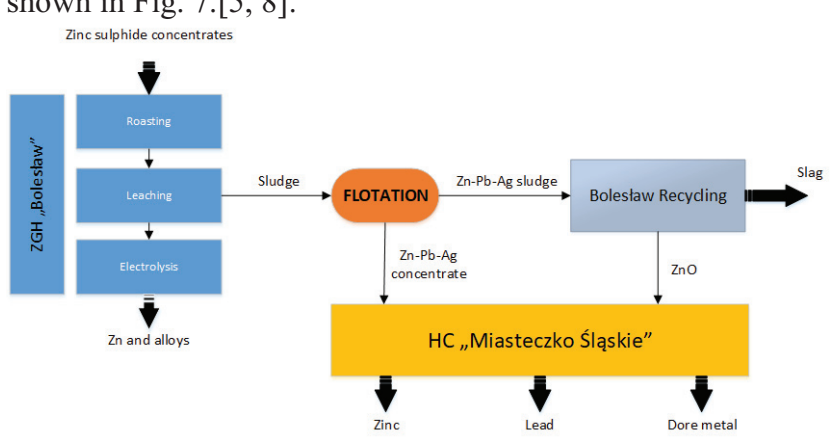

Fig. 7. Current sludge processing diagram.

The present solution has two drawbacks:

- High transportation costs to the ZPM Olkusz Pomorzany

- Low degree of post-flotation concentrate enrichment with silver (ca. 50-60\%).

Upon consideration of those two items, this study was devoted to the development of a new flotation technology, allowing for higher silver recovery from the combined concentrate $(\mathrm{Zn}-\mathrm{Pb}-\mathrm{Ag})$, in comparison to the present results. The newly prepared technology, together with the placement of the flotation process at the smelter, without the necessity to transport sludge, will allow to gain tangible economic effects.

There is only one smelter plant around the world which has the same technology as Bukowno. It is Jiyuan (YOUGUANG) Plant $[1,11,12,13]$. Construction of the Jiyuan zinc smelter, situated 10km North of Jiyuan City on a Greenfield site, started in 2003, and the plant was commissioned in September 2005 with a nominal capacity of $100 \mathrm{kt} / \mathrm{a}$ slab zinc (actual capacity possibly $120 \mathrm{kt} / \mathrm{a}$ ) at a cost of US\$79M. The zinc smelter includes an on-site coal-fired 50MW power plant, built at a further cost of US\$25M. The power plant and the Waelz kiln for residue treatment were completed several months after the main sections of the smelter were commissioned. A 10t/a indium plant costing US $\$ 2.4 \mathrm{M}$ was commissioned in mid2007 , a US\$3.6M silver flotation unit to recover silver from leach residues came on-stream in July 2006 and cadmium production commenced in March 2006. London Metal Exchange (LME) registration for SHG zinc $<\mathrm{YG}$ SHG> was obtained in June 2008.

\section{References}

1. H. Brook, Zinc Smelters and Projects Processes, Costs and Profitability (2016)

2. P. Ostrowska-Popielska, A. Sorek, Prace Instytutu Metalurgii Żelaza, 64(4), 39-46 (2012)

3. Z. Blaschke, Inżynieria Mineralna 2(20), 26-35 (2007)

4. A. Jarosiński, L. Madejska, Gospodarka Surowcami Mineralnym, 24(4) (2008)

5. K. Cichy, Z. Szołomicki, C. Reguła, Rudy Metale 52(10), 595 - 600 (2007) 
6. M. Sakata, T. Imai, A. Horiuchi K. Morita, Y. Kondo, M. Kusano, Zinc Smelters Survey, International Symposium on Lead and Zinc Processing (Kyoto, Japan, 2005)

7. M. Fatyga, Metody produkcji koncentratu zawierajacego Ag (ZGH Bolesław, 2016)

8. S. Pietrzyk et al., Ocena możliwości zwiększenia uzysku srebra w procesie flotacji szlamów po kwaśnym ługowaniu prażonki cynkowej, (ZGH Bolesław SA, Kraków 2016)

9. https://www.911 metallurgist.com/blog/processoxidized-lead-zinc-ores
10. http://minerals.usgs.gov/minerals/pubs/commodity/z inc/

11. C. Duval, D.J. Kleiner, "Lead and Zinc Production, available

http://www.tshaonline.org/handbook/online/articles/ dk101 accessed July 23, 2017,

12. http://www.ifc.org/ifcext/enviro.nsf/Content/Enviro nementalGuidelines

13. http://www.cpchem.com/bl/specchem/enus/Pages/In troductiontoMineralProcessing

14. W. Sun, J. Su, G. Zhang, Y. Hu, J. Cent. South Univ. Technol., 19(8), 2307-2315 (2012) 